\title{
Physical Activities Decrease Fasting Blood Glucose Level in Diabetes Mellitus Type 2 Patients: Use of International Physical Activity Questionnaire (IPAQ) in Rural Area
}

\author{
Mirasari Putri, ${ }^{1}$ Rd. Tiara Indah Persariningrat, ${ }^{2}$ Samsudin Surialaga, ${ }^{1}$ Mas Rizky A. A. Syamsunarno ${ }^{3}$ \\ ${ }^{1}$ Department of Biochemistry, Faculty of Medicine, Universitas Islam Bandung, Indonesia, ${ }^{2}$ Medical \\ Undergraduate Program, Faculty of Medicine, Universitas Islam Bandung, Indonesia, ${ }^{3}$ Department of Biomedical \\ Sciences, Faculty of Medicine Universitas Padjadjaran Sumedang, Indonesia
}

\begin{abstract}
An increase in the incidence of diabetes mellitus type 2 (DM-2) has been observed from 1.1\% in 2007 to $1.5 \%$ in 2018 with incidents occur in both urban areas and rural areas of Indonesia. Garut as one of the rural areas in Indonesia is the fourth district with the highest DM-2 incidence in West Java Province, Idnonesia. Physical activity is considered to affect the glycemic control and weight loss in DM-2 patients. Therefore, the purpose of this study was to determine the relation between the physical activity level and blood glucose level in DM-2 patients in Garut, Indonesia. This was a cross-sectional observational analytic study on 46 DM-2 patients who were the members of the Garut Branch of the Indonesian Diabetes Association (PERSADIA), in May 2018. The physical activity level was measured using the International Physical Activity Questionnaire (IPAQ) while the blood glucose level was measured using fasting blood glucose level test. Data were then analyzed using analysis of variance test. Results showed that most participants had a low level of physical activity $(52.2 \%)$ while the lowest fasting blood glucose was obtained from patients with high physical activity $(98.63 \pm 11.6)$, compared to those with moderate and low physical activity levels $(123.43 \pm 20.16$ and $164.21 \pm 19.04 \mathrm{mg} / \mathrm{dL}$, respectively) with $\mathrm{p}=0.000(\mathrm{p}<0.05)$. Lifestyle changes, especially in the form of the lack physical activity, were seen alsonin the rural area in Indonesia. High physical activity level is the most effective measure to lower fasting blood glucose level in DM-2 patients.
\end{abstract}

Keywords: Diabetes mellitus type 2, fasting blood glucose level, IPAQ, physical activity, rural area

\section{Aktivitas Fisik Menurunkan Kadar Glukosa Darah Puasa pada Pasien Diabetes Mellitus Tipe 2: Menggunakan the International Physical Activity Questionnaire (IPAQ) di Rural Area}

\begin{abstract}
Abstrak
Kejadian pasien diabetes mellitus tipe 2 (DM-2) pada tahun 2018 (1,5\%) mengalami peningkatan dibanding dengan tahun 2007 (1,1\%), terjadi baik di daerah perkotaan dan pedesaan di Indonesia. Garut sebagai salah satu daerah pedesaan di Indonesia adalah salah satu kabupaten dengan insidens DM-2 terbesar keempat di Jawa Barat-Indonesia. Aktivitas fisik dianggap memengaruhi kontrol glikemik dan penurunan berat badan pada pasien DM-2. Oleh karena itu, tujuan dari penelitian ini adalah mengetahui hubungan tingkat aktivitas fisik dengan kadar glukosa darah pada pasien DM-2 di Garut-Indonesia. Subjek penelitian ini adalah 46 pasien DM-2 yang tergabung dalam Persatuan Diabetes Indonesia (PERSADIA), cabang Kabupaten Garut, pada Mei 2018. Metode penelitian yang digunakan adalah analitik observasional dengan metode cross-sectional. International Physical Activity Questionnaire (IPAQ) sebagai alat untuk mengukur tingkat aktivitas fisik, selain itu dilakukan pengukuran kadar glukosa darah puasa. Data dianalisis menggunakan analysis of variance test. Hasil penelitian menunjukkan bahwa sebagian besar peserta memiliki tingkat aktivitas fisik yang rendah $(52,2 \%)$ dan glukosa darah puasa terendah diperoleh dari pasien dengan aktivitas fisik yang tinggi $(98,63 \pm 11,6)$ dibanding dengan aktivitas fisik sedang dan rendah $(123,43 \pm 20,16$ dan $164,21 \pm 19,04 \mathrm{mg} / \mathrm{dL})$, dengan $\mathrm{p}=0.000(\mathrm{p}<0,05)$. Perubahan gaya hidup terutama kurangnya aktivitas fisik juga terjadi di daerah pedesaan di Indonesia dan aktivitas fisik yang tinggi adalah tipe yang paling efektif menurunkan kadar glukosa darah puasa pada pasien DM-2.
\end{abstract}

Kata kunci: Aktivitas fisik, diabetes mellitus tipe 2, glukosa darah puasa, IPAQ pedesaan

Corresponding Author: Mirasari Putri, Department of Biochemistry, Faculty of Medicine, Universitas Islam Bandung, Jalan Taman Sari No. 22, Bandung, West Java, 40116, Indonesia, Email: putrimirasari@gmail.com 


\section{Introduction}

Diabetes Mellitus Type 2 (DM-2) prevalence increases with age, and even though it tends to be remarkably high in adults of all ages, recent findings have shown that DM-2 has also been diagnosed in adolescents. ${ }^{1}$ In US population, approximately 30.3 million people $(9.4 \%)$ had diabetes in 2015. ${ }^{2}$ Based on the Indonesian Basic Health Research (IBHR) Report, the prevalence of DM-2 patients in Indonesia was higher in 2018 $(1.5 \%)$ when compared to the same prevalence in $2007(1.1 \%)$ with both urban area $(1.89 \%)$ and rural area $(1.01 \%)$ affected by this disease. ${ }^{3}$ In 2012, the incidence of DM-2 in West Java has reached 10,000 with Garut district, a rural area in West Java,ranks fifth among the districts with the highest incidence of DM-2 with $23.7 \%$ DM-2 incidence. ${ }^{4}$

Physical activity is considered to effectively control blood glucose level in DM-2 patients. ${ }^{5}$ Our body will use glucose as fuel to produce energy when we are doing physical activities. Glucose in the body is derived from blood, liver, and also muscles. Glucose in the form of glycogen will be stored in the liver and muscles. During the first 15 minutes of physical exercise, the majority of the fuel used is from glucose in the bloodstream or glycogen in the muscle through back-conversion of glycogen into glucose. After exercising for 30 minutes, the body starts to increase glucose use from the blood, liver, and muscles to get more energy that a decrease in blood glucose level and glycogen is seen. ${ }^{6} \mathrm{~A}$ previous study by Petermann et al. ${ }^{7}$ stated that there is a significant correlation between DM-2 and physical activity level, especially for people with a family history of DM-2.The lifestyle differences in the rural and urban area contribute to cardiometabolic diseases, including DM-2. A study by Obirikorang et al. ${ }^{8}$ showed that people from urban area have a higher fasting blood sugar level than those from rural area. The cardiometabolic risk factors such as lack of physical activities, smoking, hypertension, abdominal obesity, dyslipidemia, and excessive alcohol intake are more likely found in urban society, which becomes the reason why so many studies performed in urban areas and only a few studies performed in rural areas. ${ }^{2,8,9}$ This study was intended to explore one of the cardiometabolic risks, i.e. physical activity, and its relationship with fasting blood glucose level in DM-2 patients in a rural area in Indonesia.

\section{Methods}

This study was conducted in Dr. Slamet District General Hospital in Garut district in May 2018. The participants consisted of $46 \mathrm{DM}-2$ patients who were the members of the Indonesian Diabetes Association (PERSADIA). The inclusion criterias were DM-2 patient who was a member of PERSADIA organization in Garut District, male and female, and willing to participate in the study. Meanwhile,e the exclusion criteria in this study were DM-2 patients with complications such as hypertension and cardiovascular diseases. Informed consent was signed before all procedures were started. This study was approved by the Ethics Committee of the Faculty of Medicine, Bandung Islamic University, with the issuance of the ethical clearance Number: 335/Ethics Committee.FK/III/2018.

This was an observational analytic study using cross-sectional approach. The International Physical Activity Questionnaire (IPAQ) - short form instrument was used to measure the levels of physical activities. This questionnaire has been widely used to identify the individual level of activity with a coefficient of test-rest reliability indicates a good stability with high reliability $(\alpha$ $<80) .10-12$

There are 7 questions in this questionnaire and median values and interquartile ranges can be computed for walking (W), moderate-intensity activities (M), vigorous-intensity activities (V), and a combined total physical activity score. All continuous scores are expressed in METminutes/week. There are 3 categorical scores: category 1 (Low) that represents the lowest level of physical activities consisting of individuals who dp not meet criteria for categories 2 or 3 ; category 2 (moderate) that represents a pattern of activities that include either involved in 3 or more days of vigorous-intensity activity of at least 20 minutes per day OR 5 or more days of moderate-intensity activities and/or walking of at least 30 minutes per day OR5 or more days of any combination of walking and moderate intensity or vigorous intensity activities with a minimum Total physical activity of at least 600 MET-minutes/week; and Category 3 (high) that describe higher levels of activities that meet one of the criteria of vigorous-intensity activities in at least 3 days and achieving a minimum total physical activity of at least 1,500 MET-minutes/ week OR, 7 or more days of any combination of walking and moderate-intensity or vigorous- 
Table Participant Characteristics

\begin{tabular}{llcc}
\hline \multicolumn{1}{c}{ Characteristics } & \multicolumn{1}{c}{ Category } & $\begin{array}{c}\text { Number } \\
\text { (n=46) }\end{array}$ & Percentage (\%) \\
\hline \multirow{2}{*}{ Gender } & Female & 37 & 80.4 \\
& Male & 9 & 19.6 \\
\multirow{2}{*}{ Age } & $<50$ years & 22 & 47.8 \\
& $\geq 50$ years & 24 & 52.2 \\
\multirow{2}{*}{ Physical activity } & Low & 24 & 52.2 \\
& Medium & 14 & 30.4 \\
& High & 8 & 17.4 \\
\hline
\end{tabular}

intensity activities with a minimum total physical activity of at least 3000 MET-minutes/week. ${ }^{12}$

The instrument used to determine the fasting blood glucose (FBG) levelin DM type 2 patients was a digital Glucometer (Accu-Check).

Analysis of variance (ANOVA) was used to assess the significant difference between each group ( $p$-value $<0.05=$ significant and $p$-value $<0.01=$ very significant) with LSD as the post-hoc test. The Spearman rank correlation was then test performed to show the correlation.

\section{Results}

The characteristics of DM-2 patients are listed in Table 1, showing that more in women than men participated in the study with most participants aged $>50$ years old $(52.2 \%)$. For the physical activity level, most of participants had a low level of physical activities (52.2\%).

It is shown that the FBG level in DM-2 patients ranged from $83-200 \mathrm{mg} / \mathrm{dL}$ with an average of $140.39 \mathrm{mg} / \mathrm{dL}$.

Figure shows that the highest mean of FBG level was seen in patients with low level of physical activities $(164 \pm 19.04 \mathrm{mg} / \mathrm{dL})$ while the lowest FBG was seen in patients with a high level of physical activities $(98 \pm 11.06 \mathrm{mg} / \mathrm{dL})$. The LSD post-hoc test was used to compare the groups and the results showed that patients with a high level of physical activities had a significantly lower FBG compared to the FBG in patients with low even moderate physical activity level ( $p$-value $<0.001$ ). This result was also similar to the result of comparison between FBG in patients with a moderate level of physical activities and FBG in patients with low physical activity level

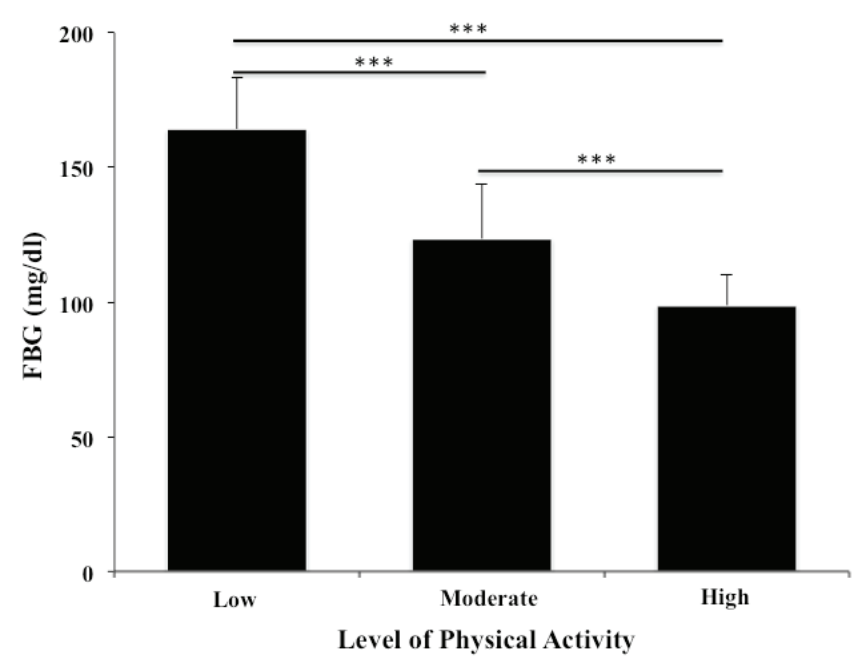

Figure FBG Decreases with increasing Physical Activity Level in DM-2 Patients

Note: Data are presented as mean \pm SD with $n=46$, statistical analysis by one way ANOVA, LSD posthoc test. ***: $\mathrm{p}<0.01=$ very significant 
(p-value<0.001).

The correlation between variables as analyzed using the Spearman rank test showed a statistically significant correlation between physical activity level and FBG level in DM-2 patients $(p=0.000, r=-0.842)$. The negative correlation coefficients reflected an opposite direction of correlation where the higher the physical activity level is, the lower the FBG level. Furthermore, people who do walking had the highest total cholesterol and LDL cholesterol levels. The strength of the correlation between these variables was very strong $(r>0.75)$.

\section{Discussions}

Blood glucose is the main carbohydrate fuel found in the blood and is the primary fuel for many organs of the body. In some parts of the body, blood glucose is the main source of energy formation while in some other parts of the body glucose is stored in the form of glycogen. ${ }^{6}$ The blood glucose level in the human body can be used as an indicator that a person has diabetes mellitus and also can be used to monitor treatment results. ${ }^{13}$

Very significant differences in FBG level between DM-2 patients with different physical activity levels were seen shere patients with a high physical activity level had the lowest average blood glucose level compared to those with moderate and low physical activity levels. Thus, the high physical activity level is the most effective physical activity level for reducing the blood glucose level. Using the correlation test, a very strong negative correlation was revealed between physical activity level and FBG level in DM-2 patients. That was, the higher the physical activity is, the lower the FBG level falls. According to the American Diabetes Association (ADA) 2019, physical inactivity is one of the DM-2 risk factors and is the reason for including physical activities in the lifestyle management for DM-2. ${ }^{12}$ Physical activities improve various metabolic processes of DM-2 patients including increasing the sensitivity of insulin, strengthening the skeletal muscles, and expanding the quadriceps muscles especially in the cross-sectional area that will increase the number of insulin receptors. ${ }^{14}$

Using the IPAQ score, it is apparent that many participants of this study were in category 1 , reflecting a low physical activity level. The possible mechanism is that low physical activity level can decrease glycolipid uptake and utilization by downregulating GLUT-4 gene expression in the skeletal muscle cells. This gene has the responsibility in improving the skeletal muscle capability by increasing glucose uptake and transport. ${ }^{14}$ It also plays a role in body mass index (BMI) optimization, DNA methylation modulation, as well as upregulating some cytokines secretion that correlates with exercises and metabolic diseases. ${ }^{15-18}$

The results of the current study are in line with the findings in a study performed by Paramitha ${ }^{19}$ in 2014 where they showed a significant relationship between physical activity and blood glucose levels in DM-2 patients in Karanganyar District General Hospital, Surakarta with $\mathrm{p}=0.001$ and $\mathrm{r}=-0.433$ and also a study by Nurayati and Adriani ${ }^{20}$ in Surabaya city in 2007. Recently, DM-2 risk is increasing with a change in the lifestyle that adopts low activity level and high carbohydrate consumption. According to IBHR 2013, the prevalence of DM-2 in urban areas in Indonesia is around $5.7 \%$. This present study was conducted in Garut district, which is, unlike Surabaya and Surakarta, not an urban area in Indonesia. According to the Health Profile of West Java Province in 2012, Garut is the fifthrank districts with the highest incidence of DM-2 with $23.7 \%$ incidence rate. ${ }^{4}$ This study showed that most DM-2 patients have low physical activity, suggesting lifestyle change also happens in the rural area.

The limitation of the study is that it does not include other risk factors such as obesity, smoking, and hypertension in the consideration. Further studies are expected to add other variables that can affect blood glucose level and also the mechanisms involved. In conclusion, lack of physical activities are also seen in Garut as one of the rural areas in Indonesia and that high physical activity level significantly reduce blood glucose level in DM-2 patients.

\section{References}

1. Keresztes P, Peacock-Johnson A. CE: type 2 diabetes: a pharmacologic update. Am J Nursing. 2019;119(3):32-40.

2. Fan W. Epidemiology in diabetes mellitus and cardiovascular disease. Cardiovascular Endocrinology Metabolism. 2017;6(1):8-16.

3. Riskesdas. Laporan Nasional Riset Kesehatan Dasar 2018. Jakarta: Kementerian Kesehatan Republik Indonesia; 2018.

4. Depkes. Profil Kesehatan Provinsi Jawa Barat 2012. Bandung: Dinas Kesehatan; 2012.

5. Association AD. 5. Lifestyle management: 
standards of medical care in diabetes-2019. Diabetes care. 2019;42(Suppl 1):S46-60.

6. Stanford KI, Goodyear LJ. Exercise and type 2 diabetes: molecular mechanisms regulating glucose uptake in skeletal muscle. Advances in Physiology Education. 2014;38(4):30814.

7. Petermann F, Diaz-Martinez $X$, GarridoMendez A, Leiva AM, Martinez MA, Salas C, et al. Association between type 2 diabetes and physical activity in individuals with family history of diabetes. Gaceta sanitaria. 2018;32(3):230-5.

8. Obirikorang C, Osakunor DNM, Anto EO, Amponsah SO, Adarkwa OK. Obesity and cardio-metabolic risk factors in an urban and rural population in the Ashanti RegionGhana: A Comparative Cross-Sectional Study. PLoS One. 2015;10(6):e0129494.

9. Al Musaimi O, Abu-Nawwas A, Al Shaer $\mathrm{D}$, Khaleel $\mathrm{N}$, Fawzi M. Influence of age, gender, smoking, diabetes, thyroid and cardiac dysfunctions on cystatin C biomarker. Medicina de Familia. Semergen. 2019;45(1):44-51.

10. Vasickova J, Groffik D, Fromel K, Chmielik F, Wasowicz W. Determining gender differences in adolescent physical activity levels using IPAQ long form and pedometers. Ann Agric Environ Med. 2013;20(4):749-55.

11. Van Poppel MN, Chinapaw MJ, Mokkink LB, Van Mechelen W, Terwee CB. Physical activity questionnaires for adults. Sports med. 2010;40(7):565-600.

12. Craig CL, Marshall AL, Sjöström M, Bauman AE, Booth ML, Ainsworth BE, et al. International physical activity questionnaire: 12-country reliability and validity. Med Sci Sports Exerc. 2003;35(8):1381-95.

13. Maharani AI, Hasmono D, Diansyah MN. Use of anti-dyslipidemia in type 2 diabetes mellitus. Indian J Public Health Res Development. 2019;10(8):1970-6.

14. American Diabetes Association (ADA). Introduction: standards of medical care in diabetes 2019. Diabetes Care. 2019;42(Suppl 1):S1-2.

15. Fonseca RM, Roschel H, Tricoli V, de Souza EO, Wilson JM, Laurentino GC, et al. Changes in exercises are more effective than in loading schemes to improve muscle strength. J Strength Cond Res. 2014;28(11):3085-92.

16. Hussey SE, McGee SL, Garnham A, McConell GK, Hargreaves M. Exercise increases skeletal muscle GLUT4 gene expression in patients with type 2 diabetes. Diabetes Obes Metab. 2012;14(8):768-71.

17. Yang D, Yang Y, Li Y, Han R. Physical exercise as therapy for type 2 diabetes mellitus: from mechanism to orientation. Ann Nutr Metab. 2019;74(4):313-21.

18. Thent ZC, Das S, Henry LJ. Role of exercise in the management of diabetes mellitus: the global scenario. PLoS One. 2013;8(11): e80436.

19. Paramitha GM. Hubungan Aktivitas fisik dengan kadar gula darah pada pasien diabetes melitus tipe 2 di Rumah Sakit Umum Daerah Karanganyar. Surakarta: Universitas Muhammadiyah Surakarta; 2014.

20. Nurayati L, Adriani M. Hubungan Aktifitas fisik dengan kadar gula darah puasa penderita diabetes melitus tipe 2 . Amerta Nutr. 2017;1(2):80-7. 